\title{
Einsteins Hirn
}

\section{Helmut Wicht}

Einsteins Hirn wurde, so entnehme ich einem überaus lesenswerten Buch $^{1}$, nach seinem Tode entnommen. Gegen Einsteins ausdrücklichen Willen, von einem räuberischen Pathologen. Das war 1955. Der Pathologe machte später eine (sehr amerikanische) »inverse Karriere« - er verbrachte seine Tage als automobiler Tramp »on the road « und in diversen »mobile homes«. Ein veritables »road-movie« also, und, wer hätte das gedacht: Einstein war mit dabei im »cast«.

Denn der Pathologe (sein Name sei hier verschwiegen, von wegen "condemnatio memoriae") hatte das Gehirn in kleine Würfel geschnitten, er hatte etliche Dutzend alte Marmeladengläser mit Konservierungsflüssigkeit gefüllt und die Hirnwürfelchen da hineingetan. Die Gläser kamen in eine alte Apfelsaftkiste, die wiederum in den Kofferraum eines angejahrten Buick Skylark, und so bereiste der gewürfelte Einstein die Staaten von Ost nach West und wieder zurück.

Ich stell mir gerade vor, was wohl passieren würde, wenn man die Würfelchen wieder zusammensetzen könnte und Einstein so wieder zum Reden brächte. Ich weiß genau, was er als erstes sagen würde:

"Gott würfelt nicht! «²

1 Das Buch heißt: »Im Museum der Gehirne«, von Brian Burrel, erschienen bei Hoffmann und Campe, 2005.

2 "Gott würfelt nicht" - das hat Einstein wirklich gesagt, weil er der statistischen, „würfelnden« Natur der Welt, wie sie die Quantenmechaniker beschrieben, misstraute. 